Breus, N., Hrybkov, S., Polischuk, G., and Seidykh, 0.

National University of Food Technologies,

68, Volodymyrska St., Kyiv, 01601, Ukraine,

+380 44287 9247, +380 66294 1304, sergio_nuft@nuft.edu.ua

\title{
DEVELOPMENT OF MATHEMATICAL APPARATUS OF THE EXPERT SYSTEM FOR MODELLING ICE CREAM RECIPES WITH SPECIFIED QUALITY PARAMETERS
}

\footnotetext{
Introduction. Application of new methods, in particular, expert systems with mathematical apparatus, enables improving the recipe composition of multi-component food products in a wide range of content of components with their full or partial replacement by alternative ones, including natural functional and technological ingredients.

Problem Statement. The creation and use of hybrid expert system of ice cream recipe modelling is impossible without using special mathematical apparatus.

Purpose. To develop mathematical models and methods that enable to calculate the multicomponent ice cream recipes with the standard chemical composition taking into account the raw materials and functional and technological ingredients available at the manufacturer and to get the finished products of guaranteed quality.

Materials and Methods. The methods of analysis and synthesis, generalization and scientific abstraction, as well as the method of mathematical modelling are used. The information base of the research is the results of laboratory studies of the quality of recipe components and ice creams of different chemical composition. Mathematical modelling with the use of tuples, systems of equations and restrictions, is made in MathCad and MathLab software packages.

Results. As a result of the development of the expert system mathematical apparatus, a set-theoretical mathematical model of the finished product quality control at the stage of operative planning of new types of ice cream with increased nutritional value has been obtained; multi-component ice cream recipes have been optimized in terms of composition; and a model for determining the optimal set of control actions in the presence of technological defects in the calculation of recipes has been built.

Conclusions. The created mathematical apparatus for modeling ice cream recipes has a large-scale application due to interchangeability of separate functional and technological components, which has been tested and confirmed during the trials in research laboratories.
}

Keywords: mathematical apparatus, expert system, optimization, and ice cream recipe modelling.

Strategic development of food technology depends on the efficiency of scholarly research and practical application of its results. While doing $\mathrm{R} \& \mathrm{D}$ works, it is necessary to assess the contribution of individual developments to the solution of problems, as well as to evaluate the prospects and to develop a strategy for the commercialization of the $\mathrm{R} \& \mathrm{D}$ results.

C BREUS, N., HRYBKOV, S., POLISCHUK, G., and SEIDYKH, O., 2019
The complexity and depth of these problems requires the involvement of highly qualified experts in the implementation of research works. In this regard, to solve the urgent problems of the food industry, which is accompanied by the systematic management of individual series of scholarly research, it is necessary to apply modern information technologies, including those based on expert systems. Such systems are the most effective tool for conducting research and commercia- 
lizing its results. With the help of expert systems, it is possible to integrate the knowledge of researchers from different fields and to create appropriate partner systems that may be used for the development of recommendations for the industry.

Now, there is a problem of creating information systems to address the specific challenges of food technology as complex multifactorial models. The final result depends on both the physicochemical parameters of the recipe ingredients and their content in the multicomponent food systems, as well as on the simultaneous effect of numerous processing parameters (mechanical, thermal, biochemical, etc.) throughout the technological production cycle on these systems.

In order to build an appropriate information system for supporting the technological processes with the help of expert knowledge, many components (technical, informational and universal mathematical apparatus represented by a complex of mathematical methods and models) are necessary. Such mathematical apparatus can be used for solving problems of modeling and optimizing the composition of various types of multicomponent food systems in a wide range of variations in the recipe composition with the application of fundamentally new functional and technological ingredients.

The problems of computer simulation of foodstuff with a given nutritional value have been studied by various researchers, including N.N. Lipatov and Yu.A. Yuvashkina in $[1,2]$. The issues of optimization of individual technological operations have been discussed by domestic and foreign researchers, including G.E. Polishchuk, Yu.A. Olenev, A.A. Tvorogova, A.E. Krasnov, O.N. Krasulia, R.T. Marshall, H.D. Goff, and R.W. Hartel [1-12].

The problems of supporting the technological processes in food industry through the use of information technologies have been very widely discussed, but so far, there have been no analogs of information systems with a universal mathematical apparatus designed to model ice cream formulations as the most complex food product in terms of chemical composition and physical characteristics.
Research in the modeling of ice cream composition has shown that, in most cases, the formulation of recipes is considered only as a task to develop a new product with original consumer properties. Such problems are usually addressed without the use of information technology that involves mathematical methods and models, and their solutions do not take into account all the specifics of modeling recipes of new types of ice cream with improved product quality.

At the same time, modeling of consumer characteristics of finished products and prediction of their functional and technological characteristics that are formed at the stage of preparation of recipe formulas is of great importance for increasing the nutritional value of products through the development of new formulations.

When modeling ice cream composition, it should be borne in mind that the term "quality" is a set of special requirements for interrelated organoleptic and physicochemical properties. The main factors that form the organoleptic perception of the consistency of the finished product are: the air volume content (ice cream overrun), the degree of dispersion of the air phase, and the resistance to melting [4-9].

It should be noted that the full-scale process of modeling any multicomponent ice-cream recipes requires considerable time and materials for laboratory research in the case of replacement of each recipe component and the choice of its optimal content.

The purpose of this research is to develop mathematical models and methods that enable to quickly calculate multicomponent formulations of ice cream with a standard chemical composition, taking into account the availability of raw materials, functional and technological ingredients for the manufacture of a finished product of guaranteed quality.

The designed mathematical apparatus of the expert system shall support the creation of recipes of new types of ice cream with specified consumer characteristics and optimal cost, as well as to select the optimal chemical composition of mix 
formulas for the formation of specified organoleptic and physicochemical properties of ice cream due to functional and technological properties of the components.

The theoretical set mathematical model of quality management of the finished product at the stage of operational planning of the recipe for new types of ice cream with a high nutritional value has a coherent (self-consistent) form $[11,13]$.

At time $T$, there is given a set of raw materials in the form of $X(T)$ i.e. set of tuples $X(T, i)$ :

$$
\begin{gathered}
X(T, i)=<X(T, i, 1), X(T, i, 2), \\
\ldots X(T, i, K+1)>,
\end{gathered}
$$

where $X(T, i, 1)$ is the quantity of $i$-th raw material in stock at the moment $T ; X(T, i, 2), X(T, i, K)$ are quality parameters of $i$-th raw material in stock at the moment $T ; K$ is the number of quality parameters.

The following equalities shall be met:

$$
\begin{gathered}
\mathrm{X}(0)=\varnothing, \\
\mathrm{X}(0)=\bigcup_{i=1}^{N} X(T, i) \\
X(T)>0 .
\end{gathered}
$$

Also, at the moment $T$ a set of additional materials is given as $X d p m(T)$ and described by tuples $\operatorname{Xdpm}(T, i)$ :

$$
\begin{gathered}
X d p m(T, i)=<\operatorname{Xdpm}(T, i, 1), \operatorname{Xdpm}(T, i, 2), \ldots \\
X d p m(T, i, K v+1)>,
\end{gathered}
$$

where $X d p m(T, i, 1)$ the quantity of $i$-th indirect material in stock at the moment $T ; X(T, i, 2)$, $\ldots X(T, i, K v+1)$ are quality parameters of $\mathrm{i}$-th indirect material in stock at the moment $T$; $K v$ is the number of quality parameters of $i$-th indirect material.

In this case, the following equalities shall be met:

$$
\begin{gathered}
X d p m(0)=\varnothing, \\
X d p m(T)=\bigcup_{i=1}^{N} X d p m(T, i), \\
X d p m(T)>0 .
\end{gathered}
$$

At the moment $T$, there is a planned assignment to produce the ice cream described as follows:

$$
\begin{aligned}
P z(T)= & <P z(T, 1), P z \max (T, 2), P z \max (T, L), \\
& \operatorname{Pzmin}(T, 2), P z \operatorname{Pmin}(T, N p)>,
\end{aligned}
$$

where $P z(T, 1))$ is the planned quantity of the ice cream to be produced; $P z \max (T, 2), \operatorname{Pzmax}(T, L)$ are maximum permissible quality parameters of the ice cream; $P z m i n(T, 2), P z m i n(T, L)$ are minimum permissible quality parameters of the ice cream; $N p$ is the number of quality parameters of the finished product.

The problem is reduced to the synthesis by operator $U$ at a given interval $d T$, which forms the tuple $R(T+d T)$ described by the expression:

$$
R(T+d T)=U(X(T), P z(T), N \operatorname{Rec}(T)),
$$

where $R(T+d T)=<X p(T+d T), X p d p m(T+d T)$, $F p(T+d T)>; X p(T+d T)$ is a set of raw material to be used within the interval $(T, T+d T)$ for manufacturing the product; $X p d p m(T+d T)$ is asset of indirect materials to be used within the interval $<T, T+d T>$ for manufacturing the product; $F p(T+d T)$ is tuple of products to be manufactured within the interval $<T, T+d T>$, $F p(T+d T)=<F p(T+d T, 1), F p(T+d T, 2), .$. $F p(T+d T, N p)>; F p(T+d T, 1)$ is the quantity of products to be manufactured; $F p(T+d T, 2)$,.. $F p(T+d T, N p)$ are quality parameters of the future products; $N \operatorname{Rec}(T)$ is new formulation developed at the moment $T$.

Let $F f(T+d T)$ is a tuple of the products manufactured within the interval $\langle T, T+d T\rangle$, then $F f(T+d T)=<F f(T+d T, 1), F f(T+d T, 2), .$. $F f(T+d T, N p)>, F f(T+d T, 1)$ is the quantity of the products manufactured within the interval $<T, T+d T>$, a $F f(T+d T, 2), . . F f(T+d T, N p)$ are quality parameters of the products manufactured.

The admissible operator $U d$ ensures the fulfillment of the inequalities:

$$
\begin{gathered}
\forall k(P z \min (T+d T, k) \leq F p(T+d T, k) \leq \\
\quad \leq \operatorname{Pzmax}(T+d T, k)), k=2, . . N p, \\
\forall k(P z \min (T+d T, k) \leq F f(T+d T, k) \leq \\
\quad \leq P \operatorname{Pmax}(T+d T, k)), k=2, . . N p .
\end{gathered}
$$

These relationships ensure obtaining the products of specified quality. 
If $X n(T+d T)$ ) is set of raw material coming to stock within the interval $<T, T+d T>$, then set of raw material at the moment $T+d T$ is defined by the relationship:

$$
\begin{gathered}
X(T+d T)=X(T) \cup X n(T+d T) \backslash \\
X p(T+d T) .
\end{gathered}
$$

For the indirect materials the relationship is as follows:

$$
\begin{gathered}
X d p m(T+d T)=X d p m(T) \cup X d p m n(T+d T) \backslash \\
X d p m p(T+d T),
\end{gathered}
$$

where $X d p m(T+d T)$ is set of indirect materials in stock at the moment $T+d T ; X d p m(T)$ is set of indirect materials in stock at the moment $T$; $\operatorname{Xdpmn}(T+d T)$ is set of indirect materials coming to stock within the interval $T, T+d T$; $X d p m p(T+d T)$ is set of indirect materials to be used within the interval $T, T+d T$.

Let the optimal operator $U_{0}$ is the admissible operator $U_{d}$, that ensures the optimal value of given criterion of effectiveness $Q$ and is defined as cost of the formulation of the ice cream. Since the technology for ice cream manufacture is a multistage and complicated process, the operator $U$ may be represented as a set of operators:

$$
U=\bigcup_{i=1}^{4} U_{i}
$$

where $U_{i}$ is the operator that forms $X p$, a set of raw material to be processed.

According to the planned assignment, the subset $X p(T)$ for processing is chosen:

$$
X p(T)=U_{1}(X(T), P z(T)) .
$$

Based on the chosen subset $X p(T)$ the operator $U_{2}$ forms a set of ingredients for making the ice cream formulation:

$$
\begin{gathered}
<Y(T), X d p m p(T)>=U_{2}(X p(T), P z(T)) \\
Y(T)=\{y(T, i)\} \quad i=1, . .,|Y(T)|, \quad \\
y(T, i)=<y(T, i, 1), y(T, i, 2), \ldots, y(T, i, M)>,
\end{gathered}
$$

where $y(T, i, 1)$ is the quantity of the $i$-th object; $y(T, i, 2), \ldots, y(T, i, M)$ are the quality parameters of the $i$-th object; $M$ is the number of quality parameters of the $i$-th object; $X d p m p(T)$ is the set of indirect materials to be used within the interval $T, T+d T$ while making the formulation.

Based on the set $Y(T)$, the operator $U_{3}$ forms the chemical composition of the ice cream formulation $Z(T)$, that can be described by the expression:

$$
\begin{gathered}
Z(T)=U_{3}(Y(T), P z(T), R), \\
Z(T)=<Z(T, 1), Z(T, 2), \ldots, Z(T, N f)>,
\end{gathered}
$$

where $Z(T, 1)$ is the planned quantity of the ice cream; $Z(T, 2), \ldots, Z(T, N f)$ are the quality parameters of the ice cream; $N f$ is the number of quality parameters.

The ice cream $Z(T)$ is transformed by the operator $U_{4}$ into the new planned finished product $F p(T+d T)$, described by the expression:

$$
F p(T+d T)=U_{4}(Z(T), P z(T)) .
$$

The tuple of actually manufactured products $F p(T+d T)$ is formed based on the factory's reports, instead of being calculated.

The problem of optimizing the formulation of ice cream is to determine the ingredient composition of the formulation using different types of raw materials having certain physicochemical characteristics and a high nutritional value [4-7].

To set the problem of optimizing multicomponent ice cream recipes, it is necessary to have complete information about the list of all types of ingredients that may be included in the formulations, quality parameters, functional and technological properties of each type of raw material, as well as the quantitative content of ingredients.

Most recipe components of milk-based ice cream are basic ones, so their contents are regulated by requirements of standards. For example, for ice cream the content of the following ingredients is standardized: sugars and sugar products; fat; stabilizer; moisture; and dry skim milk residue. Flavorings, fillers and other components are added to ice cream mix formulas according to the manufacturer's recommendations for the formation of specified organoleptic characteristics of a particular type of product. 
Let us suppose, there is given a set of ingredients described by the tuples $Y$ :

$$
Y(i)=<y(i, k)>, i=1, N ; k=1, K,
$$

where $y(i, 1)$ is minimum permissible share of the $i$-th ingredient in the recipe; $y(i, 2)$ is maximum permissible share of the $i$-th ingredient in the recipe; $y(i, 3)$ is the moisture content in the $i$-th ingredient, $\% ; y(i, 4)$ is the fat content in the $i$-th ingredient, $\% ; y(i, 5)$ is the content of sugar and sugar products in the $i$-th ingredient, $\% ; y(i, 6)$ is the content of stabilizer in the $i$-th ingredient, \%; $y(i, 7)$ is the content of dry skimmed milk residue (DSMR) in the $i$-th ingredient, $\% ; y(i, 8)$ is price per $1 \mathrm{~kg} i$-th ingredient, UAH.

The requirements for the quality parameters of the finished product are as follows:

- $K v$ (moisture), $\%-60 \leq K v \leq 72$;

- $K s$ (DSMR), \% $-8 \leq K s \leq 12$;

- $K j$ (fat), $\%-0.5 \leq K j \leq 5$;

- Kst (stabilizer, at most), \% - $0.4 \leq K s t \leq 1.5$;

- $K z$ (sugar and sugar products, at most), \% $14 \leq K z \leq 18$.

For example, for high-fat vanilla ice cream recipe, the standard values of the coefficients are as follows:

$$
\begin{gathered}
K v=65 \%, K s=10 \%, K j=15 \%, \\
K s t=0.5 \%, K z=14.5 \% .
\end{gathered}
$$

While determining the input data, it is necessary to set the following vector:

$$
x=<x(i)>, i=1, N,
$$

where $x(i)$ is weight fraction of the i-th ingredient in the recipe.

The admissible solution is vector $x$ that meets the following limitations:

- The moisture content limitation:

$$
\sum_{i=1}^{N} x(i) \cdot y(i, 3) \leq K v k
$$

- The fat content limitation:

$$
\sum_{i=1}^{N} x(i) \cdot y(i, 4) \leq K j k
$$

- The sugar content limitation:

$$
\sum_{i=1}^{N} x(i) \cdot y(i, 5) \leq K z k
$$

- The stabilizer content limitation:

$$
\sum_{i=1}^{N} x(i) \cdot y(i, 5) \leq K s t k
$$

- The DSMR limitation:

$$
\sum_{i=1}^{N} x(i) \cdot y(i, 6) \leq K s k
$$

- The sum of fractions shall be equal to 1 (the shares are determined for the unit product):

$$
\sum_{i=1}^{N} x(i)=1
$$

- The ingredient use limitation:

$$
\forall i(y(i, 1) \leq x(i) \leq y(i, 2)), i=1, N .
$$

The optimization function of the assignment is as follows:

$$
F(x)=\sum_{i=1}^{N} x(i) \cdot y(i, 8) \rightarrow \text { min } .
$$

The above described technology for designing new types of formulations enables to replace some ingredients of the recipe by their substitutes that meet all necessary requirements.

The substitute or new ingredient can be described by the equation:

$$
Y z=<y z(k)>, k=1, K,
$$

where $y z(1)$ is the minimum permissible share of the substitute in the recipe; $y z(2)$ is the maximum permissible share of the substitute in the recipe; $y z(3)$ is the moisture content in the substitute, $\%, y z(4)$ is the fat content in the substitute, $\% ; y z(5)$ is the sugar content in the substitute, $\% ; y z(6)$ is the stabilizer content in the substitute, $\% ; y z(7)$ is the DSMR content in the substitute, $\% ; y z(8)$ is price per $1 \mathrm{~kg}$ substitute, $\mathrm{UAH}$; $\mathrm{S}$ is the set of ingredient numbers.

Hence, if $k z \in S$, and ingredient $y z$ is a substitute for it the problem statement needs to be revised as follows:

- To include the substitute $y z$ into the set of ingredients under the number $N+1$;

- $\quad$ To replace $N$ by $N+1$ in formulas (18-23);

- Formula (23) for $k s t$ is written as follows:

$$
\forall(k s t, 1) \leq x(k s t)+x(N+1) \leq y(k s t, 2) ;
$$




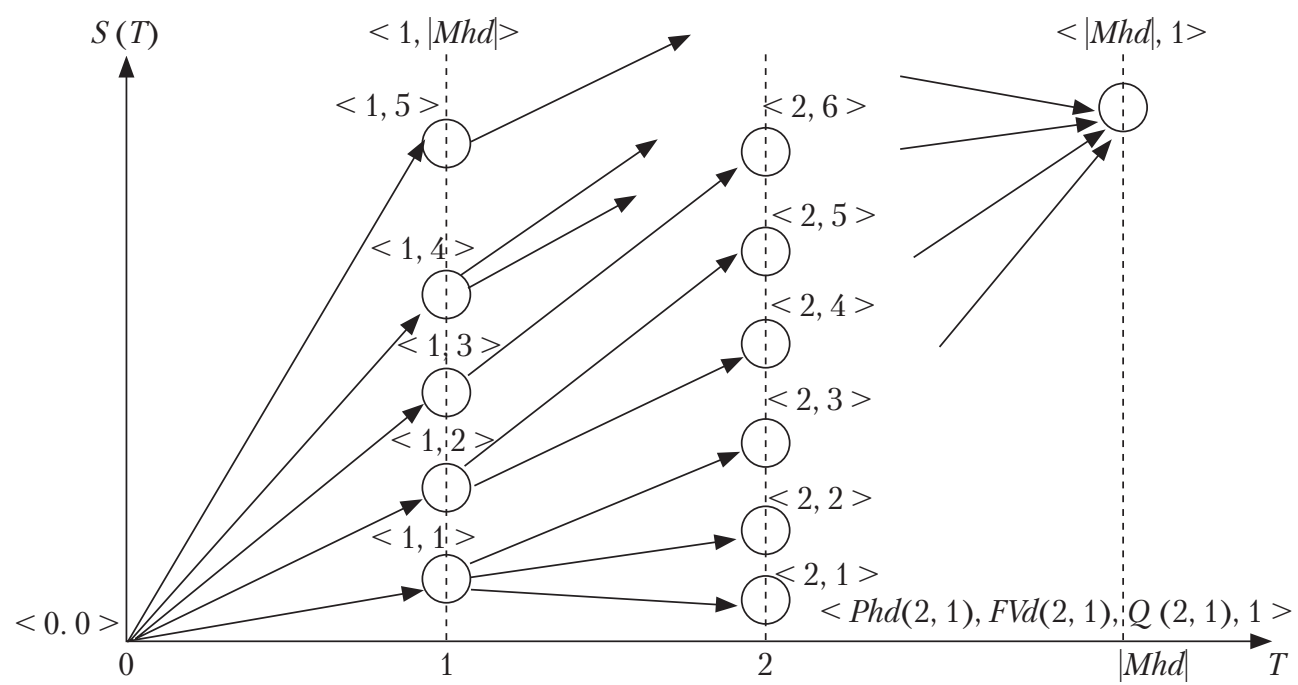

Puc. Stepwise solution building of the problem: where nom $(T-1)$ is the number of the point of previous step, from which the point at the step $T$ is obtained. The process starts with the point $<0,0>, P h d(0)=\varnothing, F V h(0)<0, \ldots 0>, Q(0)=0$. At the first step, we obtain $|M p d|$ options for forming the set Phd, each of which consists of one of the objects of the set Mhd:Phd $(1,1)$, $\operatorname{Phd}(1,1), \ldots P h d(1,|M h d|)$. At the second step, we obtain $C^{2}{ }_{\mid \text {Mhd }}$ options, at the third one, we get $C^{3}{ }_{\text {Mhd }}$ options, and at the last one, we have $C_{\mid \text {Mhd }}^{\mid \text {Mhd }} \mid$ options. This approach is a direct enumeration of problem solution options.

- For other numbers, formula (23) remains unchanged.

To solve the problem of optimization of ice cream formulations, we have used the simplex method. Its objective is to minimize the price of the product and the limitations are the quality requirements.

Having detected technological defects in ice cream formulations (for example, in the formulation with a high content of the dispersed phase, which leads to an unstable structure, with the taste and the aroma not meeting the requirements), it is necessary to adjust the set of technological, taste, and aroma properties of the product made based on the specified recipe. This set of properties is formed and corrected using the control inputs realized by adding food additives with the required functional and technological properties to the formulations [13, 14].

As a result, it is necessary to select such a list of control inputs in the form of food additives, which would contain the required set of ingredients, but at the same time, the total cost per unit mass of these additives would be minimal. The set of food additives $M h d$, each element of which $M h d(i)$ is given as tuple:

$$
\operatorname{Mhd}(i)=<\operatorname{Mhd}(i, k), \operatorname{Mhd}(i, K+1)>\text {, }
$$

where $\operatorname{Mhd}(i, k)=\left\{\begin{array}{l}1, \text { if } \operatorname{Mhd}(i) \text { possesses the } \\ k \text {-th functional property, } \\ 0, \text { otherwise. }\end{array}\right.$ $k=1, . . K$, where $K$ is the number of functional properties; $\operatorname{Mhd}(i, K+1)$ is price of the $i$-th additive.

Let the set of functional properties is given as vector:

$$
F V=<F V(1)>, I=1, \ldots, L, L \leq K,
$$

where $F V=\left\{\begin{array}{l}1, \text { if the presence of functional pro- } \\ \text { perty } l \text { is required } \\ 0, \text { otherwise. }\end{array}\right.$

Let $P h d$ is a subset of $M h d: P h d \subseteq M h d$. Let us define operator $F h$ that forms vector $F V h$ as:

$$
\begin{gathered}
F V h=F h(P h d), \\
F V h(1)=0 \ldots 1=1, \ldots, L, \\
F V h(l)=F V h(l) \vee P h d(i, 1) l=1, \ldots, L, i=1, \\
. P h d \mid .
\end{gathered}
$$


Thus, vector $F V h$ generalizes the set of functional properties that correspond to the subset $P h d$. It is necessary to find such a subset Phd for which the following conditions are met:

$$
F h(P h d)=F V \text {, }
$$

and the criterion is

$$
\mathrm{Q}=\sum_{i=1}^{\mid \text {Phd } \mid} \operatorname{Phd}(i, K+1) \rightarrow \min .
$$

The formulated task relates to the problem of the smallest vertex cover of NP-complex optimization of integer programming and is improved by the rules for rejection of unpromising variants [15-17]. Fig. 1 shows stepwise solution of this problem. In the plane $<S, T>$, where $T=0, . .|M h d|$, $S(T)$ is the ensemble of points, with the triple of values: $<P h d(T), F V h(T), Q(T), \operatorname{nom}(T-1)$, which describe the options for solution building at the step $T$ corresponding to each point of this ensemble.

Let us compare the vertex of a graph at each point of the plane $<S, T>$ and represent the obtainment of one option at each step of the solution by a graph arc. The resulting graph is a graph of allowable states (GAS). In order to reduce the dimension of the problem, it is necessary to screen out inadmissible and unpromising solutions at every step.

Let us consider the obtainment of new point $S(T+1, n)$ from point $S(T, j)$.

Let $\operatorname{Mhd}(n) \notin M h d \backslash \operatorname{Phd}(T, j)$ that creates the subsets:

$$
\begin{aligned}
& \operatorname{Phd}(T+1, n)=\operatorname{Phd}(T, j) \cup \operatorname{Mhd}(n), \\
& \operatorname{FVh}(T+1, n)=\operatorname{Fh}(\operatorname{Phd}(T+1, n)) . \\
& \text { If } \\
& F \operatorname{Vh}(T+1, n)= \\
& =F V h(T, j) \vee \exists 1(F V h(T+1, n, 1)>F V(1)) \text {, }
\end{aligned}
$$

then, the addition of new additive either does not enhance the functionality of the new subset, or increases the cost of the formulation, or this new additive provides extra functionality. Such a peak is considered inadmissible for the further development. Otherwise, the new vertex is valid. For the admissible vertex, the criterion $Q(T+1, n)$ is calculated by the following recursive relationship:

$$
Q(T+1, n)=Q(T, j)+\operatorname{Mhd}(n, K+1) .
$$

If

$$
F V h(T+1, n)=F V,
$$

then this point remains on the vertical $T+1$ as admissible and further transits to the next levels in the same status.

Let us put together each transition arc from point $<T, j>$ to point $<T+1, n>$ and $\operatorname{Mhd}(n, K+1)$ interpreted as the arc length. In this case, the solution of the problem is reduced to finding the shortest path on the GAS from the vertex $<0,0>$ to vertex $<|M h d|, 1>$.

For reducing the number of GAS vertexes, at each step the following actions shall be done: let $\operatorname{Phd}(T+1)$ is the set of all admissible points obtained at step $T+1$. Let us consider two arbitrary points on the vertical $T+1$ : $p h d(T+1, i)$ and $\operatorname{phd}(T+1, j)$, the corresponding vectors $F \operatorname{Vh}(T+1, i)$ and $F V h(T+1, j)$, and the criteria $Q(T+1, i)$ and $Q(T+1, j)$.

Point $\operatorname{Phd}(T+1, i))$ is unpromising with respect to point $\operatorname{Phd}(T+1, j)$, if the relationship is met:

$$
\begin{gathered}
\forall m(\operatorname{Phd}(T+1, j, m)) \geq \\
\geq \operatorname{Phd}(T+1, i, m) \wedge Q(T+1, i),
\end{gathered}
$$

where $m$ is the point of the state on the $<S, T>$ plane vertical.

Relationship (35) means that in the set $\operatorname{Phd}(T+1, j)$ there are more functional options as compared with the set $\operatorname{Phd}(T+1, i)$, at a lesser total cost of additives. All unpromising vertexes shall be rejected at each step of the solution building.

Mathematical models designed to optimize ice cream formulations enable to avoid defects of individual quality parameters of this product at certain stages of the manufacturing process.

The developed mathematical apparatus can be used to optimize the formulation of any other multicomponent food product, taking into account the ranges of content of the basic compo- 
nents and recommendations for the use of functional and technological food additives.

The prospects for the further research include testing the created mathematical apparatus as part of the expert system, which will improve the recipe composition of new types of ice cream by applying fundamentally new functional and technological ingredients in order to improve an important quality parameter, the nutritional value of the product. The use of an expert system will enable to calculate the optimal ice cream formulations of guaranteed quality, taking into account technological innovations, in a production environment, with minimum time input. In the case of detection of technological defects in the formulations (for example, a low content of the dispersed phase), the expert system offers recommen- dations to remedy the existing defects. The recommendations are formed by logical conclusion based on the factual knowledge base.

Hence, a new system for calculations of ice cream formulations has been developed to reduce the consumption of time and material resources for verifying the compliance of organoleptic and physicochemical parameters with the regulatory requirements for the quality of the finished product.

A mathematical apparatus for obtaining optimal ice cream recipes of a specified quality and cost, as a component of the expert system, has been developed. Unlike the conventional recipe modeling methods, the mathematical apparatus is based on the application of expert data processing technology and optimization methods.

\section{REFERENCES}

1. Lipatov, N. N., Rogov, I. A. (1987). Metodologiya proyektirovaniya produktov pitaniya s trebuyemym kompleksom pokazateley pishchevoy tsennosti. Izvestiya vuzov. Pishchevaya tekhnologiya, 2, 9-15 [in Ukrainian].

2. Ivashkin, Yu. A. (2000). Informatsionnyye tekhnologii proyektirovaniya i otsenki kachestva pishchevykh produktov napravlennogo deystviya. Myasnaya industriya, 5, 40-41 [in Ukrainian].

3. Olenev, Yu. A., Tvorogova, A. A., Kazakova, N. V., Solov'yeva, L. N. (2004). Spravochnik po proizvodstou morozhenogo. Moskva: DeLi print.

4. Goff, H. D., Hartel, W. R. (2012). Ice Cream. Springer US, New York.

5. Polischuk, G. E., Breus, N. M., Vovkodav, N. I., Ramanauskas, R. (2013). Matematicheskoye modelirovaniye aktivatsii funktsional'no-tekhnologicheskikh svoystv yablochnogo pyure. Maisto chemija ir technologija. Mokslo darbai (Food chemistry and technology. Proceedings), 47, 45-52 [in Latvia].

6. Polischuk, G. E., Ivanov, S. V., Breus, N. M. (2014). Features of ice-cream foam structure formation. Food science and technology, 2(27), 57-62 [in Ukrainian].

7. Breus, N. M., Manoha, L. U., Polischuk, G. E. (2015). Obgruntuvannya dotsil'nosti stvorennya hibrydnoyi ekspertnoyi systemy kontrolyu yakosti zamorozhenykh produktiv desertnoho pryznachennya. Naukovi pratsi Natsional noho universytetu kharchooykh tekhnolohiy, 6, 109-116 [in Ukrainian].

8. Manoha, L. U., Polischuk, G. E., Breus, N. M., Bass, O. O. (2016). Optymizatsiya skladu morozyva na molochniy osnovi z tsukrystymy rechovynamy. Naukovi pratsi Natsional'noho universytetu kharchovykh tekhnolohiy, 1, 166-172 [in Ukrainian].

9. Ustymenko, I. M., Breus, N. M., Polischuk, G. E. (2016). Naukove obgruntuvannya skladu emul'siy, pryznachenykh dlya normalizatsiyi molokovmisnykh produktiv. Naukovi pratsi Natsional'noho universytetu kharchovykh tekhnolohiy, 5, 183189 [in Ukrainian].

10. Breus, N. M., Hrybkov, S. V., Polischuk, G. E. (2017). Hybrid expert system to model the ice cream recipes. Ukrainian Journal of Food Science, 5(2), 294-305 [in Ukrainian].

11. Krasnov, A. Ye., Krasulya, O. N., Vorob’yova, A. V., Saprykina, I. D. (2007). Informatsionnoye opisaniye tekhnologicheskikh protsessov. Uchebnoprakticheskoye posobiye dlya studentov tekhnologicheskikh, upravlencheskikh i inzhenernykh spetsial'nostey. Moskva: MGUTU.

12. Portal iskusstvennogo intellekta. Ekspertnyye sistemy. URL: http://www.aiportal.ru/articles/expert-systems/ expert-systems.html (Last accessed: 19.10.2018).

13. Tokarev, A. V., Krasulia, O. N. (2015). Optimizatsiya upravlyayushchikh vozdeystviy v retsepturakh kolbasnykh izdeliy pri nalichii tekhnologicheskikh defektov. Vestnik VGUIT, 4, 66-71 [in Russia]. 
14. Sablani, S. S., Rahman, M. Shafiur, Datta, A. K., Mujumdar, A. S. (2007). Handbook of Food and Bioprocess Modeling Techniques. CRC Press Taylor \& Francis Group.

15. Sergiyenko, I. V., Gulyanitskiy, L. F., Sirenko, S. I. (2009). Klassifikatsiya prikladnykh metodov kombinatornoy optimizatsii. Kibernetika i sistemnyy analiz, 5, 71-83.

16. Blum, C., Puchinger, J., Raid, G. R., Roli, A. (2011). Hybrid metaheuristics in combinatorial optimization: A survey. Applied Soft Computing, 11(6), 4135-4151.

17. Hulianytskyi, L. F., Sirenko, S. I. (2010). Cooperative model-based metaheuristics. Electronic Notes in Discrete Mathematics, 36, 33-40 [in Ukrainian].

18. Raidl, G. R. (2006). A unified view on hybrid metaheuristics. Lect. Notes Computer Sci. Berlin: Springer-Verlag, 1-12.

19. MacGregor, R. (2013). Using a description classifier to enhance knowledge representation. IEEE Expert, 6(3), 41-46.

20. Cornelius, T. L. (2009). Expert Systems: The Technology of Knowoledge Management and Decision Making for the 21 ${ }^{\text {st }}$ Century. Academic Press.

21. Wong, B. K., Monaco, J. A. (2013). Expert system applications in business: a review and analysis of the literature. Information and Management, 3, 141-152.

Received 06.11.18

Revised 27.02.19

Accepted 18.03.19

\author{
Н.М. Бреус, С.В. Грибков, Г.Є. Полішук, О.Л. Седих \\ Національний університет харчових технологій, \\ вул. Володимирська, 68, Київ, 01601, Україна, \\ +380 44287 9247, +380 66294 1304, sergio_nuft@nuft.edu.ua \\ РОЗРОБЛЕННЯ МАТЕМАТИЧНОГО АПАРАТУ \\ ЕКСПЕРТНОЇ СИСТЕМИ ДЛЯ МОДЕЛЮВАННЯ \\ РЕЦЕПТУР МОРОЗИВА ІЗ ЗАДАНИМИ \\ ПОКАЗНИКАМИ ЯКОСТІ
}

Вступ. Застосування нових методів, зокрема експертних систем з математичним апаратом, дозволяє удосконалювати рецептурний склад багатокомпонентних харчових продуктів в широкому діапазоні вмісту складових компонентів з їх повною або частковою заміною на інші, зокрема й на натуральні функціонально-технологічні інгредієнти.

Проблематика. Створення та використання гібридної експертної системи моделювання рецептур морозива не можливо без використання особливого математичним апарату.

Мета. Розробка математичних моделей та методів, які дозволяють оперативно розраховувати багатокомпонентні рецептури морозива з нормативним хімічним складом з урахуванням наявної на підприємстві сировини й функціонально-технологічних інгредієнтів та одержувати готовий продукт гарантованої якості.

Матеріали й методи. Використано метод аналізу й синтезу, узагальнення та наукової абстракції, а також метод математичного моделювання. Інформаційною базою дослідження слугували результати лабораторних досліджень якості рецептурних компонентів та морозива різного хімічного складу. Математичне моделювання з використанням кортежів, систем рівнянь та обмежень детально здійснено у програмних пакетах MathCad та MathLab.

Результати. В ході розробки математичного апарату експертної системи було одержано теоретико-множинну математичну модель управління якістю готового продукту на етапі оперативного планування рецептури нових видів морозива підвищеної харчової цінності, оптимізовано за складом багатокомпонентні рецептури морозива, сформовано модель визначення оптимального набору керуючих впливів за наявності технологічних дефектів під час розрахунку рецептур.

Висновки. Створений математичний апарат для моделювання рецептур морозива є універсальним завдяки взаємозамінності окремих функціонально-технологічних компонентів, що перевірено та підтверджено під час його апробації у науково-дослідних лабораторіях.

Ключові слова: математичний апарат, експертна система, оптимізація, моделювання рецептур морозива. 


\section{Н.Н. Бреус, С.В. Грибков, Г.Е. Полищук, О.Л. Сєдих \\ Национальный университет пищевых технологий, ул. Владимирская, 68, Киев, 01601, Украина, +380 44287 9247, +380 66294 1304, sergio_nuft@nuft.edu.ua \\ РАЗРАБОТКА МАТЕМАТИЧЕСКОГО АППАРАТА ЭКСПЕРТНОЙ СИСТЕМЫ ДЛЯ МОДЕЛИРОВАНИЯ РЕЦЕПТУР МОРОЖЕНОГО ИЗ ЗАДАННЫМИ ПОКАЗАТЕЛЯМИ КАЧЕСТВА}

Введение. Применение новых методов, в частности экспертных систем с математическим аппаратом, позволяет совершенствовать рецептурный состав многокомпонентных пищевых продуктов в широком диапазоне содержания составляющих компонентов с их полной или частичной заменой на другие, в том числе и на натуральные функционально-технологические ингредиенты.

Проблематика. Создание и использование гибридной экспертной системы моделирования рецептур мороженого невозможно осуществить без использования особого математического аппарата.

Цель. Разработка математических моделей и методов, которые позволяют оперативно рассчитывать многокомпонентные рецептуры мороженого с нормативным химическим составом с учетом имеющихся на предприятии сырья и функционально-технологических ингредиентов и получать готовый продукт гарантированного качества.

Материалы и методы. Использован метод анализа и синтеза, обобщения и научной абстракции, а также метод математического моделирования. Информационной базой исследования послужили результаты лабораторных исследований качества рецептурных компонентов и мороженого разного химического состава. Математическое моделирование с использованием кортежей, систем уравнений и ограничений подробно осуществлено в программных пакетах MathCad и MathLab.

Результаты. В ходе разработки математического аппарата экспертной системы была получена теоретико-множественная математическая модель управления качеством готового продукта на этапе оперативного планирования рецептуры новых видов мороженого повышенной пищевой ценности, оптимизировано по составу многокомпонентные рецептуры мороженого, сформирована модель определения оптимального набора управляющих воздействий при наличии технологических дефектов при расчете рецептур.

Выводы. Созданный математический аппарат для моделирования рецептур мороженого является универсальным благодаря взаимозаменяемости отдельных функционально-технологических компонентов, что проверено и подтверждено во время его апробации в научно-исследовательских лабораториях.

Ключевые слова: математический аппарат, экспертная система, оптимизация, моделирование рецептур мороженого. 